\title{
The impact of cuts in legal aid funding of private family law
}

\section{cases}

\section{S. Wong and R. Cain}

Kent Law School, University of Kent, Canterbury, UK

\begin{abstract}
The Legal Aid, Sentencing and Punishment of Offenders Act 2012 (LASPO) made deep cuts to legal aid in the UK from April 2013, withdrawing state aid from almost all private family law cases. The paper is based on the findings of a micro-study of solicitors and Citizens Advice Bureaux (CABX) in Kent and London to investigate the impact of LASPO cuts on their work. The findings suggest that: legal aid firms have closed or merged; legal aid work is often partially carried out in solicitors' own time; 'unbundled' services for litigants in person (LIPs) are increasingly common; and family cases are being complicated and extended by the new ubiquity of the LIP. Respondents suggest that litigants may increasingly be 'giving up' on pursuing their cases, with clear implications for financial justice and contact with children. Further research is needed into the financial and affective impact of the cuts and the distribution of losses and difficulties between genders. The study, however, suggests the likelihood of post-separation poverty, debt and capital losses increasing in the post-LASPO environment, and that firms and CABx are having to find various methods of dealing with clients abandoned by the state.
\end{abstract}

\section{KEYWORDS}

Legal aid; LASPO 2012; austerity; financial justice; privatisation

\section{Introduction}

The Legal Aid, Sentencing and Punishment of Offenders Act 2012 (LASPO) made major changes to the provision of Legal Aid services in the UK. LASPO enacts some of the deep public spending cuts designed to reduce the national deficit following the 2007/8 financial crisis. One significant change was the abolition of legal aid for private family law cases unless they involved domestic violence, sexual or child abuse. The aim was to direct divorcing couples from litigation towards private settlement, a move which Mant and Wallbank (2017) call 'disappearing family law'. Following the legal aid funding cuts, many couples are no longer eligible for legal aid except through the domestic/sexual abuse (DV) gateway. However, many may be unable to afford professional legal advice or representation to resolve financial and property matters (Trinder et al. 2014). Consequently, self-representation in family law cases has increased postLASPO (Cobb 2013; Cookson 2013; Trinder et al. 2014; Eekelaar 2015; Hitchings and Miles 2016; Barlow et al. 2017). As we show here, this results in greater demands on legal practitioners and advice centres to provide new kinds of legal advice and assistance 
to divorcing couples, especially when one party is self-represented. As LASPO has been in force since 1 April 2013, it is timely to conduct research on the extent to which legal practitioners and advice centres have had to adapt their post-LASPO services to divorcing couples.

\section{Legal aid reforms in funding private family law cases}

The primary reform introduced through LASPO in relation to civil law cases is the removal of legal aid funding for divorces and private child arrangements (formerly contact/residence) disputes except through the DV 'pathways'. These pathways are restrictive and bear very high evidential requirements. The legal aid fees paid to solicitors remain low and are fixed. While LASPO enables litigants to make 'exceptional funding' applications, such applications remain rare and under-utilised, despite recent improvements to accessibility following judicial review (Pickup 2017). The Government's view is that going to court to settle family disputes should be the last resort; couples should use instead alternative dispute resolution (ADR), with mediation being heralded as the preferred choice. Hunter et al. (2017, p. 239) argue that the 'privatisation' of family law cases and the policy preference for mediation instead of court proceedings and solicitor-led negotiations reflect a neoliberal ideology of 'responsibilisation', where parties are encouraged to be responsible for resolving their 'private' disputes (Kaganas 2017; Mant 2017). Mediation Information Assessment Meetings (MIAMs), but not a full course of mediation, consequently have been made mandatory in divorce/child arrangements cases. It is important to note that most people on moderate incomes, who would struggle with the costs of litigation of any kind, would not have qualified for legal aid even before LASPO.

Amid a broader shift toward privatisation/individualisation of family litigation, the child support system in the UK has been effectively 'privatised'. The burden is placed firmly on separating couples to agree financial and childcare arrangements, without free state aid (Haux et al. 2017; Mant 2017; Mant and Wallbank 2017). The focus of our study was on investigating the effect of legal aid cuts in private family law cases involving financial relief applications and litigation. Although the sample size is small, making it difficult to draw definitive conclusions, the investigation threw up some interesting findings regarding litigation, including litigation around children.

\section{Aim of the research and methodology}

The research, funded by a small internal research grant, was conducted between May and July 2017. The aim of the research was to conduct a small-scale scoping exercise in order to investigate the effect of legal aid cuts on solicitors and advice centres within the London and Kent area. We were keen to learn more about the nature of the work that solicitors and advice centre workers have been undertaking in family law cases since LASPO came into force. We were particularly interested in finding out whether they have had to adapt their work and the types of services they provide in such cases. The research sought to ascertain whether there have been significant changes to their work as well as any challenges and/or problems they have encountered. 
The study involved in-depth interviews with six solicitors (three from urban towns in Kent and three from London), and two Citizens Advice advisers (one from an urban town in Kent and the other from London). The recruitment of the sample was on a voluntary basis and in response to emails sent to law firms and Citizen Advice offices $(\mathrm{CABx})$ in London and Kent. The law firms contacted were listed as including family law amongst their areas of practice. The solicitors in our sample were all family law practitioners, with four out of six having previous work experience in legal aid funded family law cases prior to LASPO. It was more problematic getting a reasonable sample size of $\mathrm{CABx}$ advisers, in part due to the dispersion of the type of work being done by different $\mathrm{CABx}$.

Interviews with solicitors and $\mathrm{CABx}$ advisers were conducted in either their offices or another location of their choosing. The interviews were tape-recorded and transcribed. The transcripts were then analysed, e.g. by generating categories, testing emergent understandings, searching for alternative understandings, followed by writing up the report. We have further used pseudonyms for all eight respondents for the purposes of maintaining their confidentiality. While it would be difficult to generalise the findings from a small and self-selecting sample size, the data provide some interesting insights into the ways in which solicitors and $C A B x$ have adapted their work and the types of services they provide since LASPO, and the problems and challenges they face.

\section{Findings}

One striking, but unsurprising, consequence of legal aid cuts in private family law cases is that there is now less or no more Legal Aid work being undertaken by the solicitors in our study. Most law firm respondents confirm that their firms have stopped taking on altogether (Alice, West Kent firm; Eric; Mid-Kent firm; Gabrielle, London firm), or barely do any (Beatrice, London firm; Harriet, East Kent firm) legal aid work. The main reason is the very low rates of pay for legal aid work. As most applicants are no longer eligible for legal aid unless they can use the DV or exceptional funding route, solicitors in our study state that they simply cannot take on clients who are unable to pay for legal services privately. Law firms are 'not always able to give legal assistance to someone who is unable to pay and needs help' (Celia, London firm). The reduced rates of fees paid for legally aided work had begun even prior to LASPO (Bowcott 2015). That, coupled with the reduced eligibility for legal aid funding in private family law cases, has led to a significant reduction in the volume of legal aid work for many law firms, even where clients are eligible for legal aid, and a corresponding increase in the volume of private fee-paying clients in order to keep their practices afloat. One respondent's firm, for instance, reduced their workload from a 50/50 split of private and legal aid work to about 70/30 because it is not economically viable for firms due to the low rates of pay ... which is not sustainable for law firms' (Beatrice, London firm). These views were echoed by other law firm respondents. Another respondent stated that her firm has dealt with a significantly reduced number of legal aid family law cases - probably less than six - in the past 12 months (Alice, West Kent firm). This is partly due to the difficulty of even cases that are eligible for legal aid funding through the DV gateway meeting the high evidentiary threshold. 
Where clients are eligible for legal aid, law firms that still take on, albeit on a reduced scale, legal aid family law cases have had to relegate the work to more junior colleagues, e.g. trainees and newly qualified solicitors, or increase income of privately funded work in order to help subsidise legal aid work (Beatrice, London firm). Others sought to develop a niche practice dealing with particular types of family law cases, such as, forced marriage, child abduction, care cases, wardship cases, and domestic violence injunctions, rather than ancillary relief or financial claims (Celia, London firm). In other words, law firms have had to act strategically by retaining a particular type of legal aid practice, e.g. dealing with a mixture of public and private family law (particularly through the DV gateway) cases.

Earlier research indicates that partial representation of clients in family law cases, such as, the provision of unbundled services and fixed-price packages, were increasingly being offered by solicitors (Maclean 2014; Trinder et al. 2014). Our study shows that law firms have been adapting the scope of their family law practice since LASPO. There has been certainly a shift towards the provision of unbundled services and/or reduced or fixed fee packages to clients who are not eligible for legal aid funding and may or may not be able to privately fund full legal representation. Solicitors in our study confirm that the types of unbundled services provided include the provision of ad hoc advice and assistance. For instance, Eric (Mid-Kent firm) stated that there are increasingly more 'DIY' divorces, especially the straightforward ones. While applying for a divorce is often the straightforward part, other aspects, such as, sorting out a financial relief agreement, are more complicated. However, more clients are seeking ad hoc advice, e.g. converting an agreement into consent order. Alice (West Kent firm) often provides piecemeal assistance with procedural matters, e.g. help with completing the right forms correctly, and preparing statements and applications. In most cases, respondents stated that the nature of the unbundled services provided tends to be legal advice rather than representation in court. Some added that they often restrict or are cautious about providing unbundled services because of the complexities of unpacking a case and giving advice only on certain aspects of the case (Gabrielle, London firm; Harriet, East Kent firm). 'Ad hoc advice to clients can be dangerous as the solicitor does not "get the full picture"' (Beatrice, London firm). Thus, caution must be exercised in giving ad hoc advice as it is not always possible to be fully apprised of the facts and issues of the case in order for appropriate or meaningful advice to be given (ibid; Harriet, East Kent firm).

Despite law firms in our study having scaled back or stopped taking on legal aid family law cases, all respondents confirmed that they still provide in varying degrees some legal assistance to people who contact them about family law cases and are not eligible for legal aid or do not have the means to pay. Most respondents would still take calls from people who really need help and often provide some, albeit limited, free or reduced fee services and/or signposts to where they can get help. One firm, for instance, has set up an appointments system of 15-20 minute slots several mornings per week to take calls and provide advice at significantly reduced rates, signposting and telling callers where they can get help regarding their cases (Harriet, East Kent firm). Another firm provides a brief single consultation/advice slot in order for a solicitor to give advice, such as, pointing out the relevant form(s) to fill, and telling the party which court to send it to (Beatrice, London firm). They would 'try and reduce our margins 
and give it to the most junior solicitor' in order to charge reduced private fees rates which are either comparable to Legal Aid hourly rates or half of private fee rates' (Beatrice, London firm). Some firms have had to reschedule payment of their legal fees for clients who are struggling to make payment even though that would have a knockon effect on the firm's finances (e.g. cash flow, and meeting overheads) (Beatrice, London firm).

Solicitors in our study further reported difficulties in balancing their workload between providing some legal assistance to people who are not eligible for legal aid funding and their fee-paying clients. As one solicitor commented:

'My workload has simply shifted across to my private clients. The types of clients coming to us are the same but fewer in number. Obviously, they don't have access to Legal Aid. And they are disappointed. So, we are trying to signpost them as to the amount of free advice. We have tended to do free advice ourselves, just because you don't want to see people abandoned. ... in daytime hours you are doing voluntary work [advising nonpaying clients] and in the evenings you are doing the paying work to catch up.' (Harriet, East Kent firm).

The two CABx respondents (Dana, East Kent CAB; Frances, London CAB) highlighted changes that their $\mathrm{CABx}$ have had to make in terms of the type of services provided to clients seeking legal assistance in family law cases. They have seen a significant reduction of casework relating to divorce and financial relief matters. For the East Kent CAB, work involving family law cases has year-on-year formed about $6-8 \%$ of the CAB's work. With the private family law legal aid cuts, the CAB has had to adapt to the noneligibility for legal aid funding of most clients by setting up a legal rota in order to provide some legal advice, but not representation in court, to clients (Dana, East Kent $\mathrm{CAB}$ ). Frances (London CAB) comments that, since LASPO, her CAB's work has shifted from family law cases (which previously formed the bulk of their work) towards other types of cases that predominantly relate to housing and welfare benefits matters. Both $\mathrm{CABx}$ respondents added that the assistance they are increasingly providing to family law clients is signposting them to and facilitating their contact with pro bono work and advice providers, solicitors and other advisers (e.g. University Law Clinics).

Our study reaffirms the findings of earlier research (Trinder et al. 2014; Eekelaar 2015) regarding the increase in self-representation in private family law cases as a result of post-LASPO legal aid cuts. All the firms responded that there has been an increase in dealing with litigants in person (LIPs) who are either the other party in the case or seeking unbundled services from the law firm. Gabrielle (London firm) further adds that courts are 'clogged with LIPs'. Trinder et al. have noted that there may be various reasons for self-representation which can be divided into three broad categories: costs; choice (which may be non-cost related); and difficulties with legal aid resulting in lack of legal representation (Trinder et al. 2014, p. 12). The study's responses suggest that the increased provision of unbundled services by law firms means that a proportion of LIPs (albeit not measurable from our study) are receiving 'partial representation', i.e. they had access to legal advice at some stage of, but not throughout, the court proceedings. This echoes earlier findings by Trinder et al. (2014, p. 11) where nearly half of the LIPs in their study had legal representation or advice at some stage during their case. One respondent further stated that the provision of unbundled services is not 
necessarily limited to those who are not eligible for legal aid and/or cannot pay for legal representation (Eric, Mid-Kent firm). He is encountering clients who can afford, but are unwilling, to pay for full legal representation. These litigants choose self-representation, whether fully or partially, for mixed reasons, e.g. costs saving and/or feeling competent to cope with court proceedings without legal representation - the LIPs that Trinder et al. describe as the '(apparently) competent' ones (Trinder et al. 2014, p. 24). Some solicitors observe that self-representation may even be a matter of choice for such 'competent' litigants.

One concern of our study was whether an assumption could be made that, as a result of legal aid cuts in family law cases, CABx are increasingly dealing with clients who are more likely to be LIPs, i.e. those who have been directed to CABx because they either are not eligible for legal aid or cannot pay for legal services. Dana (East Kent CAB) observed that they have had an increase in clients who are or will potentially be LIPs. Frances (London $\mathrm{CAB}$ ), however, stated that there has not been a significant change in the type of clients they are seeing since LASPO. That may be due to the type of cases that form the bulk of their work (housing, benefits, consumer and employment matters rather than divorce and, relatedly, financial dispute cases), whereas the East Kent CAB seems to deal with more family law cases. CABx are struggling to point people with complex cases to appropriate services when they are unable to provide them with help (Kirwan 2017; Low Commission 2015; Moore and Newbury, 2017). CABx advisers in our study nevertheless indicate that $\mathrm{CABx}$ have been innovative in setting up systems whereby some, however limited, legal and practical advice can be provided to people who have been referred to them. They continue to signpost clients to other possible sources of legal assistance and advice. To cope with the increasing demand for help from LIPs, the East Kent CAB established a pro bono family legal rota to set up appointments for people seeking assistance, and a DV legal rota (which operate as pop-ins and at children centres) to assist those who might be eligible for legal aid via the DV gateway. The London $\mathrm{CAB}$ has a triage system to vet which cases are more complex and set appointments to enable follow-up assistance to be provided.

Respondents echo similar problems and challenges with having to deal with LIPs noted in earlier research (Trinder et al. 2014). For instance, the rise in LIPs place a greater burden on courts and increase legal costs (Cookson 2013; Moorhead, 2010). There would be correspondingly an increase in the duration of court proceedings, longer waiting list for hearing dates and higher likelihood of adjournments (Cookson 2013). For solicitors, the delays generate more work and are time-consuming, which in turn add to costs for clients on the 'other side' who are paying for representation. Some examples given are: cases take longer as there is no solicitor on the other side to filter out the issues and advise the LIP about managing expectations, and reaching a reasonable outcome (Eric, Mid-Kent firm); mistrust on LIP's part and not being able to form a working relationship with the LIP (Alice, West Kent firm); and having to work to very tight schedules in order to give the LIP more time to look through documents before hearings (which are already set within tight court timetables) (Celia, London firm). The exceptional funding route is slow and adds to the stress and anxiety of litigants as well as slows down proceedings as hearings have to be adjourned pending the outcome of an application to the Legal Aid Agency. Gabrielle (Central London firm) reported some success with exceptional funding applications but 
found the process time consuming; no other respondents mentioned making such applications.

Delays in court proceedings are partly caused by LIPs' lack of knowledge and understanding of the law and the process, such as: lack of adequate preparation of paperwork and court process, including the hearing (Alice, West Kent firm); making a lot of mistakes and some being daunted by the process - e.g. feeling 'scared' and not understanding what is going on in court (Beatrice, London firm); and the need to explain to the LIP what the judge has said (Dana, East Kent CAB). Another respondent highlighted the added problem of LIPs not getting advice when reaching agreements: '[Litigants in person] come to me having made many mistakes in terms of the way they have handled it on their own. Reaching inappropriate financial settlements' (Harriet, East Kent firm). Having a LIP on the other side adds to the work of the solicitor for the represented party and increases outcome unpredictability: 'a nightmare' (Gabrielle, London firm). Law firm respondents further commented on the difficulties of being approached for help when a LIP hits crisis point. It may be difficult to provide advice at that stage in order to help them manage expectations, or make right points/arguments at their hearings (Celia, London firm). Some commented on the fact that selfrepresentation can be tactically advantageous as judges seem to be more patient and lenient towards a LIP; LIPs are sometimes given more leeway to present their case and a softer touch in cross-examination (Alice, West Kent firm).

One downside of self-representation in private family law cases noted by some respondents is that LIPs might not be asking for what they are entitled to, such as, seeking more child contact hours and financial relief, including pension sharing. This is because neither a judge nor the other party's solicitor would necessarily interfere and advise self-represented litigants (Celia, London firm) and, without legal aid funding, some lack the means to pay for legal advice to pursue these claims (Harriet, East Kent firm). This led one respondent to surmise as follows: 'A sad state ... bubbling longer term issues that are going to cost the state a fortune ... all these unsettling disputes, where someone might advise a client, the case you are running is outrageous and don't run it or settle' (Gabrielle, London firm). The 'simmering disputes' between separating/ separated couples without adequate access to legal advice can cause emotional and social harm to children through, e.g. prolonged conflicts, co-parenting difficulties and indebtedness, which in turn lead to a 'huge long-term cost to society' (Gabrielle, London firm). Another solicitor pointed to her experience in some cases of 'men giving up on their children' (Harriet, East Kent firm), where claims for contact and residence (child arrangements) were abandoned due to restrictions on legal aid funding.

As the CABx's role is limited to giving advice only to clients, one challenge for them in dealing with more LIPs is managing their workload with limited financial resources. Public funding is very limited and CABx are facing budget deficits; they are also heavily reliant on volunteers. That in turn places constraints on the work they can undertake: 'help is needed more beyond what we can deal with' (Dana, East Kent CAB). There are further constraints on the amount of time they can spend with clients giving assistance and advice (Frances, London $\mathrm{CAB}$ ). Both $\mathrm{CABx}$ respondents reported the growing demand for their services far outstrip what they can reasonably provide, particularly as $\mathrm{CABx}$ budgets are being squeezed. Dana (East Kent $\mathrm{CAB}$ ) states that her CAB has had 
a twenty per cent budget decrease over the past four years and there are continuing requirements to bid for funding which is allocated on a competitive basis.

The high reliance of $\mathrm{CABx}$ on volunteers raises the added issue of the levels of knowledge and expertise of volunteers to provide advice to clients, particularly in more complicated cases involving property and financial matters, and to help clients feel that the legal system is accessible. CABx respondents highlighted the difficulty of providing more training to volunteers as $\mathrm{CABx}$ budgets are being squeezed. Consequently, some $\mathrm{CABx}$ have had to tap into the wider community by referring clients to, for instance, volunteer legal professionals (e.g. solicitors, law students, barristers, etc.) from the local area. University Law Clinics form a useful resource where law students might be able to offer McKenzie Friend services (e.g. support and court presence rather than advice) (Dana, East Kent firm). It has also meant scaling down on certain types of work, such as, a reduction of debt and benefit caseworkers who would previously have been able to work with the client to deal with all aspects of their problems. However, clients with complex problems, such as, litigation-related debt, might now be dealt with in a piecemeal fashion, where problems are treated as separate and discrete. That piecemeal approach may not capture the connectedness of a client's various problems and enable assistance and advice to be given in a more holistic manner (Dana, East Kent firm).

Our study indicates that some, albeit very few, law firms are able to survive doing Legal Aid work by developing a niche practice (Celia, London firm). However, the overall, gloomier picture presented by our study is that, with legal aid funding being restricted to the DV or exceptional funding gateways, most law firms are either doing solely privately funded family law cases or increasing such work in order to subsidise some legal aid work. As mentioned above, the low legal aid fee rates provide law firms with little incentive to undertake work that is not financially viable to sustain the firm: 'There is only so much you can do in terms of charity ... the public don't realise how little we lawyers get paid' (Beatrice, London firm). Another respondent comments that 'smaller practices will not have survived [LASPO]' and that she expects firms will be surviving on 'public law work' (e.g. child protection work) (Alice, West Kent firm).

As legal aid is available only through the DV gateway, the need to find the means to pay for full representation, and even unbundled services, might be adding to the financial strain and increasing indebtedness of litigants with limited or no resources to pay. Here, two particular concerns arise regarding the emotional and wellbeing impact of litigants' non-eligibility for legal aid and, where they are eligible via the DV gateway, their failure to do so which in turn affects their perception of access to justice. For instance, Dana (East Kent CAB) cites an example of the acute distress of a female client who was afraid that her children's father would not return them after contact visits as she 'could not afford to fight him' if this occurred. One solicitor (Alice, West Kent firm) similarly relays her experience with a client 'distraught' at not qualifying for legal aid through the DV pathway because of her inability to produce the requisite evidence to meet the evidentiary threshold. Solicitors themselves report their own disappointment and unhappiness at being unable to help people and the 'mess' they see family justice in. 'I started my career really with a social conscience, you can call it that. Obviously, I do care about people getting access to advice' (Harriet, East Kent firm). The second concern that came out of our study relates to litigants taking out 
loans and/or extending credit, sometimes at high interest rates, in order to pay for legal services, including unbundled services, in private family law cases (Beatrice, London firm; Eric, Mid-Kent firm). Solicitors have commented on their clients getting into more debt in order to pay for legal services. 'They [clients] are stuck with high interest rates and that sort of thing. ... Sometimes you might think you just hope to preserve the family home, but then you would be forced into selling it to pay your litigation loan back' (Beatrice, London firm). Another respondent observes that: 'there may be some clients who are in that situation [not eligible for legal aid] that they kind of borrow, they can't afford it. They can't get legal aid whereas previously they might have been able to get it. So they borrow funds from family and friends' (Eric, Mid-Kent firm).

Solicitors mention that they often signpost clients to mediation and other ADR methods, e.g. arbitration. Mediation may be useful as mediators carry out their own filtering process to determine whether mediation is appropriate for a case (Harriet, East Kent firm). However, mediation may not be suitable for all clients. One solicitor commented on their firm's increasing use of arbitration in family law cases because arbitration is often less time and cost consuming than going to court (Gabrielle, London firm). Their experience of arbitration has been highly positive as cases are resolved much faster, taking on average about a third of the time to reach agreement (about four months instead of 12-18 months) than court proceedings. While it was acknowledged that arbitration may not be cheap, the costs to clients for the amount of work done in arbitration would be less than if the matter went to court due to the time taken to reach agreement being significantly truncated. In the light of the findings of earlier research relating to court delays, this may be an important driver for ADRs, especially when the other party is self-represented.

\section{Discussion}

The results of our study present several key questions for future research. Given the national depth of the post-financial crisis cuts, the trend of either cessation or reduction of Legal Aid work is probably replicated across the country. However, deprived and post-industrial districts such as the North East, Wales and South Yorkshire, have suffered greater damage from austerity as their populations were more dependent on public service employment and welfare, both of which suffered significant cuts since 2010 (Mattheys, Warren and Bambra, 2018in press). These areas also suffer poorer health (Schrecker and Bambra 2015), reduced life expectancy, reduced access to higher education, etc. Amid the drastic reductions in publicly funded support, information and advice services (including $\mathrm{CABx}$ ), it is likely that the legal aid cuts will have deeper 'knock-on' effects on the access to justice and financial precarity of litigants in deprived areas. A recent CAB report (2016) states that ninety per cent of litigants who are forced to represent themselves reported negative effects on various aspects of their lives, including their personal finances. StepChange (2016) has further reported that one of the top five reasons for seeking debt advice is separation/divorce; they have seen a large year-on-year increase in single parents seeking debt advice since 2012 (up from $16.1 \%$ in 2012 to $20.3 \%$ in 2016 ).

A hidden, and less investigated, effect of LASPO may be the increased indebtedness and reduced financial resources of litigants due to the lack of access to personalised 
advice on financial and property matters, including pension sharing, housing, welfare benefits, etc. Broader, national figures regarding the volume of closure or mergers of law firms across the country as a result of legal aid cuts are required. Again, we would expect to see greater impact on law firms in more deprived areas, where a greater percentage of clients and cases are likely to have been previously funded by Legal Aid. Firms may well have had to close, as some in the South East were reported to have done by respondents to this study. We would like to establish whether a majority or minority of the solicitors in previously Legal Aid dependent firms and/or in relatively deprived areas across the country have been able to find alternative employment, and what kind of work they are doing.

There seems to be some consistency in the delivery and the nature of the unbundled services being increasingly provided by law firms. Some, as we have shown, are even setting aside time in a working week to provide free, albeit limited, legal advice and assistance. Again, future research could establish how widely this pattern is replicated across the country and whether there are regional differences in the types of services being provided. The use of direct access barristers may possibly be on the rise across the UK given the increasing cost for many of using a solicitor to prepare a case. Future research could determine the extent to which parties who cannot afford full representation and are not eligible for legal aid are using direct access barristers.

There is the further question of the 'DIY' or unrepresented divorce. As noted, UK couples now receive heavy official encouragement to self-manage and privately agree the terms of their divorce. There is some evidence that 'DIY' divorces are on the increase across the country post-LASPO (McCabe 2013). As suggested by some respondents in our study, solicitors offering unbundled services may possibly take over 'DIY' divorces when these run into difficulties. It is unclear how many 'DIY' divorcers proceed to, e.g. financial relief applications, with legal representation and how many continue as LIPs, possibly using unbundled services along the way. Further research may thus be necessary.

\section{Conclusion}

From a relatively small sample, our findings nonetheless provide a striking 'snapshot' of some of the deep localised impacts of LASPO's swift and devastating costcutting. The study demonstrates that LASPO has profoundly affected professional legal practice, as well as access to justice, at the 'lower-income' level. People who would have been legal aid clients are now navigating divorce or child arrangements cases on their own or with limited access to 'unbundled' piecemeal legal advice and representation. At the $\mathrm{CAB}$ level, the responses indicate new burdens on largely voluntary advisers from clients needing to access legal advice or caught in litigation on family matters, at exactly the time that CABx funding is also being deeply cut. The post-LASPO legal landscape presents us with an almost entirely privatised UK family law (Kaganas 2017; Mant 2017, Mant and Wallbank 2017) where the vulnerable litigant is usually left to battle alone or drop out of the struggle. The general socioeconomic impact of the cuts may take several years to fully show themselves, as vulnerable litigants lose access to property (or children) they have been unable to adequately fight for. The implications for financial justice and the resulting individual debt burden in the long term are dire. From a financial justice point of view, 
the major question of borrowing to fund cases arises. Increasing indebtedness, particularly among women who have fewer assets and more caring responsibilities, could be a major long-term impact of LASPO (StepChange 2016).

Our study demonstrates the emotional/affective impact of an environment of privatisation and cuts on litigators/advisers and litigants. Thus, LASPO perhaps encapsulates the responsibilisation/privatisation burden of a post-austerity neoliberal nation, as the inefficiencies caused by rapid cost-cutting lead to large (and largely uncalculated) costs which must be borne by individuals (and to a lesser extent, law firms).

\section{Disclosure statement}

No potential conflict of interest was reported by the authors.

\section{References}

Barlow, A., et al., 2017. Mapping paths to family justice: resolving family disputes in neoliberal times. London: Palgrave.

Bowcott, O. 10 June 2015. Legal aid fees to be cut by $8.75 \%$, confirms Ministry of Justice. Guardian. Available from: https://www.theguardian.com/law/2015/jun/10/legal-aid-fees-to-becut-by-875-confirms-ministry-of-justice

https://www.citizensadvice.org.uk/about-us/policy/policy-research-topics/justice-policy-research /access-to-justice-policy-research-and-consultation-responses/access-to-justice-consultationresponses/standing-alone-going-to-the-family-court-without-a-lawyer/

Cobb, S., 2013. Legal aid reform: its impact on family law. Journal of Social Welfare and Family Law, 35 (1), 3-19.

Cookson, G., 2013. Analysing the economic justification for the reforms to social welfare and family law legal aid. Journal of Social Welfare and Family Law, 35 (1), 21-41.

Eekelaar, J., 2015. Litigants in person - the struggle for justice. Journal of Social Welfare and Family Law, 37 (4), 463-466.

Haux, T., McKay, S., and Cain, R., 2017. Shared care after separation in the United Kingdom: limited data, limited practice? Family Court Review, 55 (4), 572-585.

Hitchings, E. and Miles, J., 2016. Mediation, financial remedies, information provision and legal advice: the post-LASPO conundrum. Journal of Social Welfare and Family Law, 38 (2), 175-195.

Hunter, R., et al., 2017. Access to what? LASPO and mediation. In: A. Flynn and J. Hodgson, eds. Access to justice \& legal aid: comparative perspective on unmet legal need. Oxford: Hart Publishing, 239-254.

Kaganas, F., 2017. Justifying the LASPO act: authenticity, necessity, suitability, responsibility and autonomy. Journal of Social Welfare and Family Law, 39 (2), 168-188.

Kirwan, S., 2017. The end of 'tea and sympathy'? The changing role of voluntary advice services in enabling 'access to justice. In: A. Flynn and J. Hodgson, eds. Access to justice \& legal aid: comparative perspective on unmet legal need. Oxford: Hart Publishing, 179-194.

Low Commission. 2015. Getting It Right in Social Welfare Law: The Low Commission's Follow-up Report. Available from the Low Commission's website: https://www.lowcommission.org.uk/ dyn/1435772523695/Getting_it_Right_Report_web.pdf

Maclean, M., 2014. The changing professional landscape. Family Law, 44, 177-179.

Mant, J., 2017. Neoliberalism, family law and the cost of access to justice. Journal of Social Welfare and Family Law, 39 (2), 246-258.

Mant, J. and Wallbank, J., 2017. The mysterious case of disappearing family law and the shrinking vulnerable subject: the shifting sands of family law's jurisdiction. Social \& legal studies, 26 (5), 629-648. 
Mattheys, K., Warren, J., and Bambra, C., 2018. "Treading in sand": A qualitative study of the impact of austerity on inequalities in mental health. Social Policy and Administration, 52(7), 1275-1280http://onlinelibrary.wiley.com/doi/10.1111/spol.12348/epdf.

McCabe, M. 19 August 2013. DIY divorce on the rise after cuts to family legal aid. Legal Voice. Available from: http://www.legalvoice.org.uk/more-couples-opt-for-diy-divorce-as-legal-feesrise/

Pickup, A. 10 April 2017. How safe is the legal aid 'safety net'?' OpenDemocracy. Available from: https://www.opendemocracy.net/openjustice/alison-picku/how-safe-is-legal-aid-safety-net

Schrecker, T. and Bambra, C., 2015. How politics make us sick: neoliberal epidemics. London: Palgrave.

StepChange. 2016. Personal debt first half 2016: statistics mid-yearbook. Available from StepChange website: https://www.stepchange.org/policy-and-research/personal-debt-statistics -2016-mid-yearbook.aspx

Trinder, L., et al., 2014. Litigants in person in private family law cases. London: Ministry of Justice Analytical Series. 